\title{
Effects of sudden melon intake on ruminal parameters of non-adapted sheep ${ }^{1}$
}

\author{
Francisco L.C. Oliveira ${ }^{2}$, Raimundo A. Barrêto Júnior ${ }^{3}$, Antonio H.H. Minervino ${ }^{4}$, \\ Marcondes Dias Tavares ${ }^{3}$, Rodolfo Gurgel Vale ${ }^{3}$, Carolina Akiko Sato Cabral \\ Araújo $^{2}$, Rejane Santos Sousa ${ }^{2}$ and Enrico Lippi Ortolani ${ }^{2 *}$
}

\begin{abstract}
Oliveira F.L.C., Barrêto Júnior R.A., Minervino A.H.H., Tavares M.D., Vale R.G., Araújo C.A.S.C., Sousa R.S. \& Ortolani E.L. 2016. Effects of sudden melon intake on ruminal parameters of non-adapted sheep. Pesquisa Veterinária Brasileira 36(5):378-382. Departamento de Clínica Médica, Faculdade de Medicina Veterinária e Zootecnia, Universidade de São Paulo, Av. Prof. Dr. Orlando Marques de Paiva 86, Cidade Universitária, São Paulo, SP 05508-270, Brazil. E-mail: ortolani@usp.br

This study evaluated the effects of varying amounts of melon with high sugar content offered to sheep without prior melon experience and that were not adapted to consuming it. We used 12 eight-month-old, rumen-cannulated crossbred sheep weighing $25 \mathrm{~kg}$ each. The animals received a base diet of roughage, and then half were randomly selected to have $25 \%$ of their diet replaced with melon (G25\%) and the other half had 75\% of their diet replaced with melon (75\%). Ruminal fluid was collected before administration of melon and at 0,3 , $6,12,18$, and $24 \mathrm{~h}$ after the administration of the fruit. Sheep from the G25\% group presented volatile fatty acid ruminal acidosis (sub-acute) between 3 and $6 \mathrm{~h}$ after consumption. This acidosis was characterized by a rumen $\mathrm{pH}$ slightly lower than 5.6, increased discrete L-lactic acid content, and increased redox potential (RP) and methylene blue redox (MBR) time of the ruminal fluid. The G75\% group presented lactic ruminal acidosis at T6h, characterized by a rumen $\mathrm{pH}$ lower than 5.0, high lactate-L content, increased RP and MBR time, and increased ruminal fluid osmolarity. Therefore, offering large amounts of melon $(75 \%$ of dry matter (DM)) is not recommended but $25 \%$ of DM of this fruit can be used safely.

INDEX TERMS: Melon, acidosis, rumen, sheep, fruits, pH, lactate.
\end{abstract}

RESUMO.- [Efeitos da ingestão súbita de melão sobre os parâmetros ruminais de ovinos não adaptados.] 0 presente estudo avaliou o efeito da adição à dieta de duas diferentes quantidades de melão com alto teor de açucares oferecidos subitamente à ovinos não adaptados. Foram utilizados 12 ovinos mestiços da raça Santa Inês, com 8 meses de idade e pesando cerca der $25 \mathrm{~kg}$ providos de

\footnotetext{
${ }^{1}$ Received on October 1, 2015.

Accepted for publication on March 20, 2016.

${ }^{2}$ Departamento de Clínica Médica, Faculdade de Medicina Veterinária e Zootecnia (FMVZ), Universidade de São Paulo (USP), Av. Prof. Dr. Orlando Marques de Paiva 86, Cidade Universitária, São Paulo, SP 05508270. Brazil. *Corresponding author: ortolani@usp.br

${ }^{3}$ Departamento de Ciência Animal, Universidade Federal Rural do Semiárido (UFERSA), Av. Francisco Mota 572, Costa e Silva, Mossoró, RN 59625-900, Brazil.

${ }^{4}$ Instituto de Biodiversidade e Floresta (IBEF), Universidade Federal do Oeste do Pará (UFOPA), Av. Vera Paz s/n, Salé, Santarém, PA 68000-000, Brazil. E-mail: ah.minervino@gmail.com
}

cânula ruminal. Os animais recebiam dieta à base de volumoso e foram aleatoriamente divididos em dois grupos iguais que receberam 25 ou $75 \%$ de adição de melão picado à dieta. Foram coletadas amostras de conteúdo ruminal nos momentos zero e após 3, 6, 12, 18, e 24 horas da administração do melão. Ovinos do grupo G25\% apresentaram acidose por ácido graxo voláteis (subaguda) entre 3 e 6 horas, caracterizada por $\mathrm{pH}$ ruminal ligeiramente abaixo de 5,6, aumento discreto na concentração de ácido láctico L e aumento do potencial redox (PR) e tempo de redução do azul de metileno (TRAM) do fluido ruminal. 0 grupo G75\% apresentou acidose láctica ruminal com pH menor que 5,0, alta concentração de Lactato-L e aumento do PR e TRAM e da osmolaridade ruminal. Em conclusão, o oferecimento de grandes quantidades de melão (75\% da MS) não é recomendado, mas $25 \%$ da MS desta fruta pode ser utilizada na dieta de ovinos com segurança.

TERMOS DE INDEXAÇÃO: Melão, acidose, rúmen, ovinos, frutas, $\mathrm{pH}$, lactato. 


\section{INTRODUCTION}

Intensification of sheep farming systems, modeled after systems developed for cattle, leads to similar problems in sheep as in intensively farmed cattle. Nutritional and metabolic disorders have emerged in large numbers of intensively farmed sheep over recent years (Vieira et al. 2006). Rumen lactic acidosis is one of the major disorders and develops due to excessive ingestion of soluble carbohydrates by animals that are not adapted to such a diet as often occurs in intensive farming systems (Dunlop 1972, Dougherty et al. 1975, Nagaraja \& Titgemeyer 2007, Barrêto-Júnior et al. 2008) .

Due to the high availability and occasional surpluses of melon (Cucumis melo), this fruit has been used as an alternative feed source for sheep (Lima et al. 2012) and has become an option for supplementing ruminants during food shortages in semi-arid northeastern Brazil (Araújo et al. 2009, Lima et al. 2011, Lima et al. 2012, Oliveira et al. 2015a). However, there is a lack of studies on the risks that accompany melon-induced acidosis in non-adapted animals.

The sudden ingestion of carbohydrates causes a decrease in rumen $\mathrm{pH}$. A pH below 6.0 for prolonged periods promotes the growth of amylolytic bacteria while inhibiting the growth of cellulolytic bacteria (Krajcarski-Hunt et al. 2002). When rumen $\mathrm{pH}$ drops to 5.8, the bicarbonate concentration also decreases, causing the buffering capacity to decline, threatening rumen microbiota as well as the animal. Additionally, lactate-utilizing bacteria proliferate, and the production of volatile fatty acids (VFAs) increases (Bannink et al., 2008). Thus, the first vulnerability threshold for rumen epithelium is at a pH of 5.8 and is due to changes in the microbial composition and subsequent possibility of an inflammatory response (Gozho et al., 2005). If the pH drops to approximately 5.0, protozoans begin dying and populations of lactic acid bacteria surge, especially for Streptococcus bovis. Thus, pH 5.0 is the second vulnerability threshold for the rumen epithelium owing to compromised rumen epithelium transport capacity (Aschenbach \& Gabel 2000).

Two types of rumen acidosis exist: the first type, known as subacute rumen acidosis, is relatively mild and is caused by excess VFAs, particularly propionic acid (pK 4.8), and occurs when rumen $\mathrm{pH}$ falls below normal levels (5.9-7.2) but remains between 5.6 and 5.1 without necessarily involving clear clinical symptoms (Owens et al. 1998, Krause et al. 2006, Nagaraja \& Titgemeyer 2007). The second type, known as rumen lactic acidosis, is more severe and, in addition to the excess VFAs produced in early stages, involves a large quantity of lactic acid that greatly reduces the $\mathrm{pH}$ (below 5.1) due to its strong acidifying potential ( $\mathrm{pK}=3.7$ ). This accumulation of acids creates a condition that can involve anorexia, dehydration, diarrhea, general depression, tachycardia, an enlarged left ventral flank, metabolic acidosis, and other disorders (Dunlop 1972, Ortolani et al. 1980, Owens et al. 1998. Radostits et al. 2007, Oliveira et al. 2015b).

In this context, studies investigating varying proportions of carbohydrates in the diet of sheep require careful assessment and special attention to changes in the rumen environment, especially given that rumen stability is im- portant for animal health and, accordingly, for productivity. The aim of the present study was to test the effect of two quantities of fresh melon, which has high sugar content, on rumen health in sheep that are not adapted to consuming this fruit, with an emphasis on the occurrence of rumen acidosis.

\section{MATERIALS AND METHODS}

Animals and feeding. This study was approved by the local animal ethics commission. Twelve male crossbred Santa Inês sheep fitted with rumen cannula were used. The sheep weighed approximately $25 \mathrm{~kg}$ and were 8 months old. The animals were housed in group pens with free access to water and a mineral mixture. They were fed a base diet consisting of roughage (Cynodon dactylon (L) Pers, Coast cross hay) provided at $2.3 \%$ of live weight. The sheep had never been fed concentrate, melon pulp, or other fruits or roots. The sheep were habituated to the facilities and the feeding routine for 30 days. The lot was treated for worms using endectocide with Moxidectin.

Experimental design. The sheep were randomly distributed into two groups of six animals each: one which had 25\% dry matter (DM) melon added to the diet (G25\%); and one which received an addition of 75\% DM melon. All sheep were submitted to 12 hours fasting before melon supplementation. Sampling of ruminal content was conducted at six times: immediately before administering melon (baseline; T0) and at 3 hours (T3h), 6 hours (T6h), 12 hours (T12h), 18 hours (T18h) and 24 hours (T24h) after supplementation. Due to animal welfare, after 24 hours of the experiment all sheep that presented signs of illness were treated according to the protocol described by Rodrigues et al. (2011). The rationale for testing the effects of $25 \%$ and $75 \%$ supplementation was to simulate how this fruit is used by local farmers. Melon is used either to supplement $20 \%-30 \%$ of the diet or as the main food source for sheep and goats in the dry season, given ad libitum for a dietary intake of 70\%-80\% (Oliveira et al. 2015a).

Melon supply. The degrees Brix were measured using a digital refractometer with a 0 to $45^{\circ} \mathrm{Brix}\left({ }^{\circ} \mathrm{Bx}\right)$ scale and used to select the fruits. Chemical analysis of the melons was performed following the protocol described by the Association of Official Analytical Chemists (1992). The melons used averaged $12.5 \pm 0.3^{\circ} \mathrm{Bx}$, $7.3 \pm 0.2 \%$ dry matter, $9.30 \%$ mineral matter, $90.70 \%$ organic matter, $11.58 \%$ crude protein, $7.62 \%$ ether extract, $20.58 \%$ neutral detergent fiber, $16.68 \%$ acid detergent fiber, $69.94 \%$ total carbohydrates, $49.36 \%$ non-fiber carbohydrates, and 5.86\% lignin.

Melon was delivered intra-ruminally using a cannula. The whole fruit except the seeds was puréed to a paste in a conventional blender. The amount of paste delivered was calculated based on an average dry matter intake for $2.3 \%$ of the live weight of the sheep. Sheep weighing $25 \mathrm{~kg}$ in groups G25\% and G75\% would thus receive 1,970 and 5,90 g of processed fruit, respectively.

Sampling rumen contents. The rumen contents were sampled at each time point using a plastic hose inserted through a flexible metal probe introduced in the rumen through the rumen cannula. A vacuum/pressure pump was used to aspirate the rumen contents into a $1 \mathrm{~L}$ glass jar. Approximately $150 \mathrm{~mL}$ of rumen content was collected directly from the ventral posterior sac and used to measure the following variables: $\mathrm{pH}$, L-lactic acid, rumen osmolarity, methylene blue reduction (MBR) time, and redox potential (RP). Immediately after collection, $20 \mathrm{~mL}$ of rumen fluid was removed from the jar to measure $\mathrm{pH}$ and $\mathrm{RP}$ using a microprocessor $\mathrm{pH}$ meter previously calibrated following the manufacturer's instructions. The MBR time was measured as recommended by Wenzel (1977). 
Laboratory analyses. L-lactic acid was measured with the enzymatic UV method using lactate dehydrogenase on an automated biochemical analyzer with a commercial kit. Rumen content osmolarity was measured with a freezing point osmometer.

Statistical analysis. Comparisons between groups were initially tested with a Kolmogorov-Smirnov test. Variables with Gaussian distributions were analyzed with a repeated measures two-way ANOVA followed by the Bonferroni post-hoc test to assess differences between experimental groups and sampling times. Linear regression and the coefficient of determination $\left(r^{2}\right)$ were determined to study the relationships between pairs of variables. The level of significance was set at $5 \%$. Analyses were performed using the statistical software GraphPad Prism (version 6.0).

\section{RESULTS}

Table 1 shows the mean and standard deviation of rumen $\mathrm{pH}$ and L-lactate concentration over the course of the experiment. Rumen $\mathrm{pH}$ in the G25\% group was low at T3h and $\mathrm{T} 6 \mathrm{~h}$, rose slightly by $\mathrm{T} 12 \mathrm{~h}$, and returned to baseline by the end of the experiment $(\mathrm{P}<0.05)$. In the $\mathrm{G} 75 \%$ group, rumen $\mathrm{pH}$ fell gradually from $\mathrm{T} 3 \mathrm{~h}$ to $\mathrm{T} 12 \mathrm{~h}$ and then remained stable until the end of the experiment. There were no significant differences in rumen $\mathrm{pH}$ between groups from baseline to T3h $(\mathrm{P}>0.05)$. From T3h to the end of the experiment, however, the rumen of the G75\% group was more acidic than that of the G25\% group $\mathrm{P}<0.0001$ ).

The highest lactic acid concentrations were recorded at $\mathrm{T} 3 \mathrm{~h}$ and $\mathrm{T} 6 \mathrm{~h}$ in the $\mathrm{G} 25 \%$ group $(\mathrm{P}<0.02)$, whereas

Table 1. Mean (M) \pm standard deviation (SD) of ruminal $\mathrm{pH}$ and L-lactate concentrations in sheep subjected to sudden intake of $25 \%$ or $75 \%$ melon in their diet

\begin{tabular}{cccccc}
\hline Time (h) & \multicolumn{2}{c}{$\mathrm{pH}$} & & \multicolumn{2}{c}{ L-lactate $(\mathrm{mMol} / \mathrm{L})$} \\
\cline { 2 - 3 } \cline { 5 - 6 } & $\begin{array}{c}\mathrm{G} 25 \% \\
(\mathrm{M} \pm \mathrm{SD})\end{array}$ & $\begin{array}{c}\mathrm{G} 75 \% \\
(\mathrm{M} \pm \mathrm{SD})\end{array}$ & & $\begin{array}{c}\mathrm{G} 25 \% \\
(\mathrm{M} \pm \mathrm{SD})\end{array}$ & $\begin{array}{c}\mathrm{G} 75 \% \\
(\mathrm{M} \pm \mathrm{SD})\end{array}$ \\
\hline 0 & $6.58^{\mathrm{a}} \pm 0.13$ & $6.33^{\mathrm{a}} \pm 0.33$ & & $0.03^{\mathrm{b}} \pm 0.01$ & $0.03^{\mathrm{d}} \pm 0.01$ \\
3 & $5.52^{\mathrm{C}} \pm 0.13$ & $5.81^{\mathrm{b}} \pm 0.10$ & & $3.68^{\mathrm{a}} \pm 1.34$ & $0.38^{\mathrm{d}} \pm 0.18$ \\
6 & $5.59^{\mathrm{Ab}} \pm 0.27$ & $4.98^{\mathrm{BC}} \pm 0.22$ & & $7.42^{\mathrm{a}} \pm 4.77$ & $16.01^{\mathrm{c}} \pm 10.42$ \\
12 & $5.86^{\mathrm{Ab}} \pm 0.15$ & $4.45^{\mathrm{Bd}} \pm 0.23$ & & $0.04^{\mathrm{Bb}} \pm 0.02$ & $45.99^{\mathrm{Ab}} \pm 17.92$ \\
18 & $6.33^{\mathrm{Aa}} \pm 0.24$ & $4.35^{\mathrm{Bd}} \pm 0.12$ & & $0.04^{\mathrm{Bb}} \pm 0.02$ & $61.11^{\mathrm{Aa}} \pm 10.08$ \\
24 & $6.4^{\mathrm{Aa}} \pm 0.19$ & $4.41^{\mathrm{Bd}} \pm 0.19$ & & $0.04^{\mathrm{Bb}} \pm 0.01$ & $57.87^{\mathrm{Aab}} \pm 9.35$
\end{tabular}

Different capital letters within a line refer to statistical differences between groups (e.g., G25\% and G75\%). Different lowercase letters within a column refer to statistical differences between time points within a group. $\mathrm{P}$-values were set at $\mathrm{P}<0.05$ for all tests. the highest concentrations in the G75\% group occurred from $\mathrm{T} 6 \mathrm{~h}$ onward $(\mathrm{P}<0.01)$. There was no significant difference in rumen content L-lactic acid concentration between groups through T6h. From T12h to the end of the experiment, however, L-lactate concentrations were higher in the G75\% group compared to the G25\% group $(\mathrm{P}<0.0001)$.

Table 2 shows the means and standard deviations for osmolarity, RP and MBR time of the rumen contents over the course of the experiment. Relative to the baseline, RP was greater in the G25\% group from $\mathrm{T} 3 \mathrm{~h}$ to $\mathrm{T} 12 \mathrm{~h}$ and returned to baseline after T18h $(\mathrm{P}<0.05)$. The RP of the rumen contents in the G75\% group increased after T6h $(\mathrm{P}<0.05)$. There were no significant differences between groups in the RP of the rumen content through T12h. From T18h through the end of the experiment, the G75\% group had a greater RP than the G25\% group ( $\mathrm{P}<0.01)$.

The MBR time in the G25\% group was greater than baseline at $\mathrm{T} 3 \mathrm{~h}, \mathrm{~T} 6 \mathrm{~h}$, and $\mathrm{T} 12 \mathrm{~h}(\mathrm{P}<0.05)$. In the G75\% group, the MBR time rose after T6h and then leveled off until the end of the experiment $(\mathrm{P}<0.001)$. There were no significant differences between groups in the MBR time through $\mathrm{T} 12 \mathrm{~h}(\mathrm{P}>0.05)$. From $\mathrm{T} 18 \mathrm{~h}$ to the end of the experiment, the G75\% group had a greater MBR time than the G25\% group $(\mathrm{P}<0.05)$. The osmolarity of the rumen contents was high in the G25\% group at T3h and T6h and then fell gradually over time $(\mathrm{P}<0.05)$. The osmolarity of the rumen contents in the G75\% group rose from T3h to T12h but fell at $\mathrm{T} 24 \mathrm{~h}(\mathrm{P}<0.05)$. There was no significant difference between groups regarding osmolarity of the rumen content at baseline, but from T3h through the end of the experiment, there were more molecules in the G75\% group than the $\mathrm{G} 25 \%$ group $(\mathrm{P}<0.0001)$. In the correlation analysis, we found strong relationships between RP and MBR $\left(r^{2}=\right.$ $0.8512)$, rumen $\mathrm{pH}$ and $\mathrm{RP}\left(r^{2}=0.9543\right)$, and $\mathrm{pH}$ and MBR time $\left(r^{2}=0.86\right)$.

\section{DISCUSSION}

The rumen $\mathrm{pH}$ measurements revealed that all of the sheep in the study exhibited some degree of rumen acidosis. In the G25\% group, this condition was generally restricted to the first three hours and extended to a lesser degree 6 hours after feeding. The $\mathrm{pH}$ during this time ranged from 5.18 to 5.6, which is a clear sign of a type of rumen acidosis

Table 2. Mean (M) and standard deviation (SD) of ruminal osmolarity, redox potential (RP) and methylene blue reduction (MBR) in sheep subjected to sudden intake of 25 or $75 \%$ of melon in their diet

\begin{tabular}{|c|c|c|c|c|c|c|}
\hline \multirow[t]{2}{*}{ Time (h) } & \multicolumn{2}{|c|}{ Osmolarity (mOsm/L) } & \multicolumn{2}{|c|}{$\mathrm{RP}(\mathrm{mV})$} & \multicolumn{2}{|c|}{ MBR (min.) } \\
\hline & $\begin{array}{c}\mathrm{G} 25 \% \\
(\mathrm{M} \pm \mathrm{SD})\end{array}$ & $\begin{array}{c}\mathrm{G} 75 \% \\
(\mathrm{M} \pm \mathrm{SD})\end{array}$ & $\begin{array}{l}\mathrm{G} 25 \% \\
(\mathrm{M} \pm \mathrm{SD})\end{array}$ & $\begin{array}{c}\mathrm{G} 75 \% \\
(\mathrm{M} \pm \mathrm{SD})\end{array}$ & $\begin{array}{c}\mathrm{G} 25 \% \\
(\mathrm{M} \pm \mathrm{SD})\end{array}$ & $\begin{array}{c}\mathrm{G} 75 \% \\
(\mathrm{M} \pm \mathrm{SD})\end{array}$ \\
\hline 0 & $214.7^{\mathrm{bc}} \pm 54.8$ & $231.3^{c} \pm 26$ & $11.2^{\mathrm{b}} \pm 3.87$ & $15.0^{b} \pm 16.6$ & $3.0^{\mathrm{b}} \pm 0.9$ & $3.2^{\mathrm{b}} \pm 0.8$ \\
\hline 3 & $279^{\mathrm{Ba}} \pm 14.4$ & $354.8^{\mathrm{Aa}} \pm 14.5$ & $63.5^{\mathrm{a}} \pm 16.1$ & $53.7^{\mathrm{ab}} \pm 6.8$ & $5.3^{\mathrm{a}} \pm 0.8$ & $6.5^{\mathrm{ab}} \pm 2.1$ \\
\hline 6 & $253.8^{\mathrm{Bab}} \pm 23.7$ & $331.8^{\mathrm{Aab}} \pm 47.8$ & $66.0^{\mathrm{a}} \pm 15.6$ & $91.8^{\mathrm{a}} \pm$ & $5.5^{\mathrm{a}} \pm 1.0$ & $10.5^{\mathrm{a}} \pm 4.0$ \\
\hline 12 & $215.5^{\mathrm{Bbc}} \pm 10.5$ & $297^{\mathrm{Aab}} \pm 47.7$ & $50.0^{\mathrm{a}} \pm 9.4$ & $101.8^{\mathrm{a}} \pm 55.1$ & $6.5^{\mathrm{a}} \pm 1.5$ & $11.2^{\mathrm{a}} \pm 6.0$ \\
\hline 18 & $202^{\mathrm{Bb}} \pm 30.2$ & $281.3^{\mathrm{Abc}} \pm 69.5$ & $19.7^{\mathrm{Bb}} \pm 13.7$ & $96.5^{\mathrm{Aa}} \pm 65.4$ & $4.8^{\mathrm{Bab}} \pm 0.4$ & $11.0^{\mathrm{Aa}} \pm 6.2$ \\
\hline 24 & $179.5^{\mathrm{Bc}} \pm 21.5$ & $261.8^{\mathrm{Ac}} \pm 47.9$ & $15.8^{\mathrm{Bb}} \pm 11.3$ & $86.2^{\mathrm{Aa}} \pm 68.8$ & $4.0^{\mathrm{Bab}} \pm 1.1$ & $11.0^{\mathrm{Aa}} \pm 6.2$ \\
\hline
\end{tabular}

Different capital letters within a line refer to statistical differences between groups (e.g., G25\% and G75\%). Different lowercase letters within columns refer to differences between time points within each group. $\mathrm{P}$-values were set at $\mathrm{P}<0.05$ for all tests. 
known as sub-acute acidosis that is caused by the presence of VFAs and defined by Owens et al. (1998), Krause et al. (2006) and Nagaraja and Titgemeyer (2007). This type of acidosis results from the ingestion of feed containing a greater amount of soluble carbohydrate, which causes the animal to ingest more feed than normal, but not in excess. This extra feed contains fibrous carbohydrates that slightly stimulate the production of saliva, which is the main rumen-buffering agent (Enemark 2008).

The selected melons contained high levels of total soluble solids (BRIX), which reflects a large amount of sugar that is primarily composed of sucrose (Hubbard et al. 1989). According to Ortolani et al. (1980), mono- and disaccharides are the first substrates fermented by rumen bacteria. This fermentation begins one hour after ingesting the sugars, peaks after three hours, and plateaus by five hours. This pattern was demonstrated by the rumen $\mathrm{pH}$ in the G25\% group in this study. The primary VFA produced by such fermentation is propionic acid. Due to its relatively low pK (4.8), this acid causes slight and transient acidosis in the rumen (Enemark, 2008). Accordingly, the rumen $\mathrm{pH}$ in this study returned to baseline after 12 hours.

It should be noted that there was a significant increase in lactic acid production in the G25\% group after 3 and 6 hours. This increase was temporary, and the lactic acid concentration dropped sharply over the following period. These findings suggest that lactic acid was most likely consumed by lactolytic bacteria that converted it into a much weaker acid (propionic acid). The presence and activity of such bacteria occur when the $\mathrm{pH}$ is above 5.2 (Dunlop 1972) as occurred in the present study. Dunlop (1972) also showed that these bacteria convert lactic acid faster at a higher $\mathrm{pH}$, which explains the very low concentrations found after 12 hours.

The $\mathrm{pH}$ for the G75\% group was similar to that of the G25\% group through 3 hours, and then quickly fell by 6 hours and continued to drop until 18 hours post-consumption. In all animals in the group, this decrease was followed by a large increase in rumen lactic acid concentration, which is characteristic of the typical profile of a rumen presenting lactic acidosis, e.g.., a pH lower than 5.1 (Dunlop 1972, Owens et al. 1998, Maruta \& Ortolani 2002).

The lowest pH measured for the G25\% group occurred at 3 hours post-melon consumption and was 10-fold lower than baseline for the group. In contrast, the lowest $\mathrm{pH}$ measured for the G75\% group occurred after 18 hours post-consumption and was 100-fold lower than baseline for the group. Decreases in rumen $\mathrm{pH}$ are strongly influenced by rumen lactic acid concentration, and the intensity of rumen acidosis is directly linked to the accumulation of this strong acid (pK 3.7; Dunlop 1972, Owens et al. 1998).

On average, the G25\% animals received 1,970g and the G75\% animals received 5,900g of the original melon matter. The pulp accounts for $55 \%$ of the weight of a ripe melon (Franco 1992, Artés et al. 1993). Mean Brix for the melons was $12^{\circ} \mathrm{Bx}$. Thus, the amount of sugar delivered to the animals was estimated to be $130 \mathrm{~g}$ and $389.4 \mathrm{~g}$ of sugar for $\mathrm{G} 25 \%$ and $\mathrm{G} 75 \%$, respectively; these amounts translate to $5.2 \mathrm{~g} / \mathrm{kg} \mathrm{LW}$ and $15.6 \mathrm{~g} / \mathrm{kg} \mathrm{LW}$ respectively.
The means obtained here for minimum rumen $\mathrm{pH}$ and maximum lactic acid concentration in the G75\% group were similar to those described by Kezar \& Church (1979) who induced rumen lactic acidosis by intra-ruminal delivery of $15 \mathrm{~g}$ sucrose/ $\mathrm{kg} \mathrm{LW}$. That amount is very similar to the amount we supplied to the G75\% group (15.6g/kg LW). Considering the low rumen $\mathrm{pH}$ in the $\mathrm{G} 75 \%$ group, the sucrose present in the fruit was completely fermented by 18 hours, when decreasing $\mathrm{pH}$ leveled off and trended upward at the subsequent time point ( 24 hours).

The present study showed that both RP and MBR time were strongly correlated and increased in the G75\% group. Similarly, rumen $\mathrm{pH}$ and $\mathrm{RP}$ as well as $\mathrm{pH}$ and MBR time were also strongly correlated. Under normal conditions, the rumen environment is anaerobic with a very negative $\mathrm{RP}$ (normal values $=-110 \mathrm{mV}$; Marden et al. 2005) that reflects the absence of oxygen and a strong reduction capacity. However, the drop in $\mathrm{pH}$ and subsequently intensifying rumen acidosis halted the activity of various oxygen-reducing bacteria that entered the rumen through feeding and rumination, thereby increasing oxygen levels in the rumen environment (Broberg 1957). Such an accumulation of oxygen increases the rumen's oxidative capacity and raises the RP levels obtained (Baldwin \& Emery 1960). The above normal RP observed in this study could be due to 12 hours of fasting prior to feeding that could have caused the increase in RP due to fewer oxygen-reducing bacteria being present (Broberg 1957).

The MBR assay is based on the ability of rumen microorganisms to reduce methylene blue, which begins in the oxidized state, becomes clear when reduced, and has physiological values of up to three minutes (Wenzel 1977). Thus, methylene blue resembles oxygen in the medium when reduced. If the oxygen levels of the rumen fluid are very high, the MBR time will increase. The present study found that oxygen accumulated and MBR time increased in clear cases of rumen lactic acidosis (e.g., in the G75\% group) as well as in less severe temporary cases of acidosis caused by VFAs (e.g., in the G25\% group). As should be expected, both the low rumen $\mathrm{pH}$ and high $\mathrm{RP}$ affected MBR results. According to Soares et al. (2006), the MBR assay is considered a sensible test for identifying changes in the rumen microbiota, whether by a decrease in quantity resulting in rumen biochemical failure or by replacement and disappearance of the flora and fauna in the case of rumen acidosis.

The animals in this study had never before been fed melon or any other high-energy concentrates, yet the minimum rumen $\mathrm{pH}$ for the G25\% group caused only slight acidosis for a few hours resulting in a small change in the rumen microbiota as reflected by the PR and MBR time. Thus, it can be inferred that if these sheep were fed gradually increasing amounts of melon to adapt them to the concentrates, in a short amount of time, they could ingest quantities of melon greater than the $25 \%$ supplied in the present study.

The osmolarity of the rumen content significantly increased in both groups over the first hours of the experiment. However, osmolarity only remained above the normal limit $(300 \mathrm{mOsm} / \mathrm{L})$ in the G75\% group at T3h and T6h (Garza et 
al. 1989). At those two time points, L-lactate $(16 \mathrm{mM} / \mathrm{L})$ was only above normal levels at T6h. This finding suggests that hyperosmolarity at those times was caused by an increase in VFAs, because these acids are produced in excess during the onset of acidosis (Dunlop 1972, Owens et al. 1998). Although large quantities of rumen lactic acid were produced starting at 6 hours post-consumption in the G75\% group, this acid was most likely diluted by large amounts of fluid from the delivered melon that prevented an actual increase in osmolarity.

\section{CONCLUSIONS}

Sudden intra-ruminal delivery of high-Brix melon in non-adapted sheep caused discrete acidosis from VFAs in animals that received feed consisting of $25 \%$ melon up to 6 hours post-consumption.

The acidosis was characterized by slight changes in $\mathrm{pH}$, $\mathrm{RP}$ and MBR in the rumen contents.

Sheep that received feed consisting of 75\% melon exhibited a sharp drop in rumen $\mathrm{pH}$, an increase in lactic acid concentration, rumen flora disorders, and a temporary increase in rumen osmolarity.

Therefore, to offer large amounts of melon (75\% of dry matter (DM)) is not recommended, but $25 \%$ of DM of the fruit can be used safely.

\section{REFERENCES}

Araújo C.G.F., Silva V.N., Braga A.P. \& Rangel A.H.N. 2009. Utilização do refugo de melão (Cucumis melo L.) na suplementação de borregos na caatinga. Revista Verde de Agroecologia e Desenvolvimento Sustentável 4:98-102.

Artés F., Escriche A.J., Martinez J.A. \& Marin J.G. 1993. Quality factors in four varieties of melons (Cucumis melo L.). J. Food Quality 16:91-100.

Aschenbach J.R. \& Gabel G. 2000. Effect and absorption of histamine in sheep rumen: Significance of acidotic epithelial damage. J. Anim. Sci. 78:464-470.

Association of Official Analytical Chemists (AOAC). Official Methods of Analysis of the AOAC . 10.ed. Washington, 1992.1115p.

Baldwin R.L. \& Emery R.S. 1960. The oxidation reduction potential of rumen contents. J. Dairy Sci. 43:506-511.

Bannink A., France J., Lopez S., Gerrits W.J.J., Kebreab E., Tamminga S. \& Dijkstra J. 2008. Modelling the implications of feeding strategy on rumen fermentation and functioning of the rumen wall. Anim. Feed Sci. Technol. 143:3-26.

Barrêto Júnior R.A., Minervino A.H.H., Rodrigues F.A.M.L., Antonelli A.C., Mori C.S., Sucupira M.C.A. \& Ortolani E.L. 2008. Avaliação do potencial da polpa cítrica em provocar acidose láctica ruminal aguda em bovinos. Braz. J. Vet. Res. Anim. Sci. 45:419-427.

Broberg G. 1957. Measurements of the redox potential in rumen contents. III. Investigations into the effect of oxygen on the redox potential and quantitative in vitro determinations of the capacity of rumen contents to consume oxygen. Nordisk Vet. Med. 9:942-950.

Dougherty R.W., Riley J.L. \& Cook H.M. 1975. Changes in motility and pH in the digestive tract of experimentally overfed sheep, Am. J. Vet. Res. 36:827-829.

Dunlop R.H. 1972. Pathogenesis of ruminant lactic acidosis. Adv. Vet. Sci. Comp. Med. 16:259-302.

Enemark J.M.D. 2008. The monitoring, prevention and treatment of sub -acute ruminal acidosis (SARA): a review. Vet. Journal 176:32-43.

Franco G. 1992. Tabela de Composição Química dos Alimentos. Atheneu, São Paulo. 230p.

Garza J.D., Owens F.N. \& Breazile J.E. 1989. Effects of diet on ruminal liquid and on blood serum osmolality and hematocrit in feedlot heifers, Oklahoma Agric. Exp. Stn MP-127, p.68-76.
Gozho G.N., Plaizier J.C., Krause D.O., Kennedy A.D. \& Wittenberg K.M. 2005. Subacute ruminal acidosis induces ruminal lipopolysaccharide endotoxin release and triggers an inflammatory response. J. Dairy Sci. 88:1399-1403.

Hubbard N.L., Huber S.C. \& Pharr DM 1989. Sucrosephosphate synthase and acid invertase as determinants of sucrose concentration in developing muskmelon (Cucumis melo L.) fruits. Plant Physiology 91:1527-1534.

Kezar W.W. \& Church D.C. 1979. Ruminal changes during the onset and recovery of induced lactic acidosis in sheep. J. Anim. Sci. 49:1161-1167.

Krajcarski-Hunt H.J.C., Plaizier J.P., Walton R., Spratt B.W. \& McBride B.W. 2002. Effect of subacute ruminal acidosis on in situ fiber digestion in lactating dairy cows. J. Dairy Sci. 85:570-573.

Krause K.M., Garrett M. \& Oetzel R. 2006. Understanding and preventing subacute ruminal acidosis in dairy herds: a review. Anim. Feed Sci. Technol. 126:215-236.

Lima C.A.C., Lima G.F.C., Costa R.G., Medeiros A.N., Aguiar E.M. \& Júniors V.L. 2012. Efeito de níveis de melão em substituição ao milho moído sobre o desempenho, o consumo e a digestibilidade dos nutrientes em ovinos Morada Nova. Revta Bras. Zootec. 41:164-171.

Lima G.F.C., Silva J.G.M., Aguiar E.M., Ferreira M.A., Rangel A.H.N. \& Torres J.F. 2011. Frutos-refugo de melão em substituição ao farelo de trigo na alimentação de vacas leiteiras. Revta Caatinga 24:190-197.

Marden J.P., Bayourthe C., Enjalbert F. \& Moncoulon R. 2005. A new device for measuring kinetics of ruminal $\mathrm{pH}$ and redox potential in dairy cow. J. Dairy Sci. 88:277-281.

Maruta C.A. \& Ortolani E.L. 2002. Susceptibilidade de bovinos das raças Jersey e Gir à acidose láctica ruminal. II. Acidose metabólica e metabolização do lactato-L. Ciência Rural 32:61-65.

Nagaraja T.G. \& Titgemeyer E.C. 2007. Ruminal acidosis in beef cattle: the current microbiological and nutritional outlook. J. Dairy Sci. 90(Suppl.1):E17-38.

Oliveira F.L.C., Barrêto-Júnior R.A., Minervino A.H.H., Reis L.F., Araújo C.A.S.C., Rodrigues F.A.M.L., Sousa R.S., Gameleira J.S., Souza F.J.A., Mori C.S. \& Ortolani E.L. 2015a. Avaliação hemogasométrica, bioquímica e hematológica de ovinos suplementados com melão. Arq. Bras. Med. Vet. Zootec. 67:1272-1278.

Oliveira F.L.C., Barrêto-Júnior R.A., Minervino A.H.H., Reis L.F., Tavares M.D., Vale R.G., Gameleira J.S., Souza FJ.A., Mori C.S. \& Ortolani E.L. 2015b. Clinical evaluation of non-adapted sheep submited to sudden intake of melon with high levels of sugar. Semina: Ciências Agrárias 36(6):3721-3730.

Ortolani E.L., Birgel E.H. \& Araújo L.M. 1980. Comportamento do pH do suco de rúmen dos bovinos in vitro. Arqs Esc. Vet. UFMG 32:217-223.

Owens F.N., Secrist D.S., Hill W.J. \& Gill D.R. 1998. Acidosis in cattle: a review. J. Anim. Sci. 76:275-286.

Radostits O.M., Gay C.C., Hinchcliff K.W. \& Constable P.D. 2007. Veterinary Medicine. 10th ed. Elsevier Saunders, London. 2156p.

Rodrigues F.A.M.L., Minervino A.H.H., Barrêto Júnior R.A., Antonelli A.C., Reis L.F., Araújo C.A.S.C., Ferreira R.N.F., Vechiato T.A.F., Mori C.S. \& Ortolani E.L. 2011. Avaliação clínica do uso de solução salina hipertônica no tratamento de acidose láctica ruminal aguda em bovinos. Braz. J. Vet. Res. Anim. Sci. 48:446-453.

Soares P.C., Maruta C.A., Sucupira M.C.A., Mori C.S., Kitamura S.S., Antonelli A.C. \& Ortolani E.L. 2006. Diagnóstico da carência energética em bovinos por meio teste de metabolismo ruminal. Braz. J. Vet. Res. Anim. Sci. 43:33-41.

Vieira A.C.S., Afonso J.A.B., Mendonça C.L., Costa N.A.I. \& Souza M.I. 2006. Estudo retrospectivo da acidose láctica em caprinos e ovinos atendidos na Clínica de Bovinos, Campus Garanhuns/UFRPE. Revta Bras. Ciênc. Agrárias, Recife, 1: 97-101.

Wenzel. H. 1977. Vergleichende Prüfung der Methylenblauprobe, der Resazurinprobe, des Nitrittests und der Glukosegärprobe in der klinischen Pansensaftuntersuchung bei Rind und Schaf. Dissertation, Tiermedizinische Fakultät, Ludwig-Maximilian-Universität, München. 94p. 